\title{
Academic identity tensions in the public university: which values really matter?
}

\author{
Dr Richard P Winter \\ Research School of Management, Australian National University, Canberra, ACT 0200. \\ Tel: 0261254721 \\ richard.winter@anu.edu.au \\ Dr Wayne O’Donohue \\ Department of Employment Relations \& Human Resources, Griffith University, Gold \\ Coast, QLD 4222 \\ w.odonohue@griffith.edu.au
}

\begin{abstract}
Our study explores the relationship between values and academic identity in the public university. Framing the study is the proposition public universities face academic identity tensions arising from pressures to combine and sustain competing and contradictory managerial (economic) and academic (professional) values systems. Academic responses to an online survey indicated professors and lecturers shared a deep-seated antipathy to a market ethos that reduces higher education to a narrow economic function. Implications and challenges associated with academic identity tensions are considered.
\end{abstract}

Keywords: academic identity; public university; values

\section{Introduction}

Understanding the relationship between values and academic identity may be regarded by some managers and academics as a futile activity. But values underpin all aspects of academic and university life. As core cognitive beliefs, values serve as guiding principles in people's lives by shaping individual preferences and governing modes of thought (Beyer, 1981; Sproull, 1981). Values are central to defining the identity of individuals (Ashforth, 2001) and organisations (Albert \& Whetten, 1985). In a moral sense, values shape the rights and wrongs of behaviour by assigning moral meanings to specific actions (e.g., 'education breaks the poverty cycle') and by legitimating particular codes of academic conduct (e.g., 'academics must generate external income given government funding constraints'). Indeed, values are central to helping individuals and institutions make sense of who they in the context of past, present and future experiences (Henkel, 2005). Hence, understanding what values matter to academic staff in a university is a worthwhile activity as values help shape the behaviour and identities of academics and the institution - now and in the future.

In public universities, perhaps the 'most value-laden institutions in modern society' (Scott, 2004, p. 439), liberal values of truth and critical enquiry, an appreciation of learning and scholarship, and a passion for intellectual freedom have a long tradition of defining the essential elements of academic and university identities (Becher \& Trowler, 2001; Coady, 2000; Hussey \& Smith, 2010). But as governments position higher education primarily in terms of a narrow, economic role (McArthur, 2011), unitary business values and practices originating in the private sector are 'squeezing out' broader liberal education values and goals of the public university (Deem, Hillyard, \& Reed, 2008; Hussey \& Smith, 2010; Kolsaker, 2008). Crucially, economic-consumer conceptions of higher education and associated systems of corporate management are taking centre stage as major sensitising issues framing 
the nature of academic work and identity (Billot, 2010; Churchman \& King, 2009; Furedi, 2011; Hussey \& Smith, 2010; Winter, 2009).

An important identity shaping issue for the public university is knowing the extent to which the new corporate culture and its market positioning sits realistically aside how academics view higher education and academic work. One particular area of concern is tensions in academic identity since this signifies a different values conception of the academic self to that prescribed by the university - a role strain that affects academic motivation, self-efficacy, commitment, job satisfaction and effectiveness (Billot, 2010; Churchman \& King, 2009; Day, Kington, Stobart, \& Sammons, 2006). In our study, we attempt to gain insights into academic identity tensions by drawing attention to the different sets of values academics espouse in an Australian public university.

In making academic identity tensions explicit, we pay particular attention to the language used by academics when revealing their preferences for a managerial or professional (academic) values conception of higher education and academic work (Phillips \& Hardy, 2002). Specifically, we treated value statements as windows into the identities of academics occupying various 'fixed and largely taken-for-granted positions' in the university hierarchical structure (Ashforth, 2001, p. 4). Implicit in our theoretical position is the notion value conflict statements signify states of academic identity tension arising from pressures to align the institution and its academic workforce around a corporate management ethos and student as consumer principles (Brown \& Humphreys, 2006; Hussey \& Smith, 2010; Teelken, 2012; Winter, 2009).

\section{Values and academic identity tension}

Our conception of academic identity tension is predicated on the competing managerial (economic-private) and academic (liberal-social) values systems shaping public universities in Australia, the UK and New Zealand (Billot, 2010; Deem et al., 2008; Kolsaker, 2008; Teelken, 2012; Winter, 2009). We view academic identity as a salient characteristic of public universities given these 'hybrid' structures are organised around distinct academic discipline and manager occupational groups (Becher \& Trowler, 2001; Winter, 2009). Each group exhibits a strong perception that its own set of 'managerial-utilitarian' and 'professionalnormative' values and goals constitutes the central purpose of the university (Deem et al., 2008). Constant restructuring makes identity tensions inevitable in these environments given the intractable problem of trying to integrate narrow economic and broader social conceptions of higher education into one single entity (e.g, to satisfy the job/work requirements of student customers; to educate students; to engage in scholarly research; to increase external income; to contribute to a civilised society). Aligning values and goals under some unifying corporate vision is fraught with difficulty in this multiple-identity environment given university managers, education administrators, and academics tend to identify more with members of their own subcultures rather than as members of the university (Lewicki, Greenberger, \& Coyne, 2007).

Exactly how academic identity tensions form over time in universities is still not fully known. However, research of changing governance structures in Australian and UK universities (Deem, 1998; Deem et al., 2008; Teelken, 2012; Winter \& Sarros, 2002) suggests managerialism is an important identity shaping mechanism given it encompasses 'ideology, discourses and axioms originating in the private sector' (Kolsaker, 2008, p. 514). That is, managerialism and its associated values of economic, market-based rationality have created the values-based conditions by which some academics align themselves with the university as 
an enterprise (managerial identity), whilst others separate their academic selves from the demands of a corporate enterprise (professional identity). In effect, schisms in academic identity have emerged as academics respond to the demands of a more corporate-oriented work environment (Winter, 2009).

Academic identity tension may reveal itself when academics express frustration and misgivings at having to view students as customers and courses as products (Sharrock, 2000; Winter \& Sarros, 2002). Academics taking on a managerial-oriented identity seem able to tie their values and interests to 'the management of student learning' (Henkel, 1997, p. 138) and rendering satisfaction to students as important customers with real stakes in their own learning (Barnett, 2011). Conversely, academics with a strong sense of professional identity (Nixon, 1996) express fears that managerialism represents a deliberate attempt to commodify education and reduce knowledge itself to narrow outcomes that can be exchanged for economic gain (Furedi, 2011; Winter \& Sarros, 2002). For these academics, identity tension is a recurring issue given academic work redefined in narrow corporate terms discounts normative liberal-social values such as discipline inquiry, intellectual truth, scholarship, and knowledge that contributes to the social welfare of all members of society (Coady, 2000; McArthur, 2011; Nixon, 1997).

\section{Research strategy}

The context for the study is an Australian public university employing approximately 952 full-time equivalent (FTE) teaching and research academics (excluding research fellow and post doctoral positions). The FTE academic population were organised by faculties and represented five main discipline areas: science, engineering and technology (34 per cent), health science ( 31 per cent), arts (19 per cent), business/law ( 9 per cent) and education ( 7 per cent).

As a hybrid organisation, the university like other public universities of its size faces identity problems arising from competing pressures to integrate economic and social purposes of higher education into its operations and strategic agenda (Kenny, 2009; McArthur, 2011). These pressures are exemplified in the university's strategic vision of recognising the need for innovation and entrepreneurial activity whilst simultaneously stressing a social justice agenda of making opportunities available to the local community.

\section{Data collection}

An online survey was considered the most effective means for exploring the relationship between values and academic identity across the university (Sue \& Ritter, 2007). To ensure the survey sample was broadly representative of the FTE academic population, academics were drawn from the university's main discipline areas and stratified into 'professorial' (17 deans/associate deans; 129 professors/heads of school; 74 associate professors/deputy heads; $\mathrm{n}=220$ ) and 'lecturing' (173 senior lecturers; 280 lecturers; 81 associate lecturers; $\mathrm{n}=534$ ) positions. Accordingly, 754 academics were contacted by e-mail and invited to complete an online survey in accordance with an approved ethical consent protocol.

The online survey yielded 186 responses, an overall response rate of 25 per cent. Respondents categorised as lecturing $(n=139,75$ per cent) and professorial $(n=47,25$ per cent) positions were broadly in proportion to the sample (71 per cent and 29 per cent respectively). Most respondents were female (60 per cent), in teaching and research roles (70 per cent) and employed on an ongoing academic basis (69 per cent). The average age of respondents was 46 years. 
The online survey included four questions designed to provoke academics to reveal their value preferences in respect to the: (1) nature/purpose of higher education (i.e., higher education is best promoted on the basis of..?); (2) character/purpose of universities (i.e., universities are first and foremost..?); (3) primary purpose of academic work (i.e., the purpose of academic work is to..?); and (4) role obligations of academics (i.e., academics need to offer students..?). Each question was based on the competing managerial (economic-utilitarian) and professional (liberal-normative) values previously outlined and found to have good face validity when pre-tested with twelve academics from the first author's university.

In order to trigger associations to identity, survey items were framed as binary value statements and participants asked to choose a managerial or professional value conception of higher education, universities and academic work. According to Kerlinger (1986, p. 461), the paired comparisons technique is the 'most satisfying of psychometric methods' when the focus is on forcing participants to choose among value alternatives. In order for participants to justify their value preference and/or indicate a preference for a managerial value and professional value (i.e., hybrid identity), an open-ended comments box was included after each survey question. Hybrid identity comments are not presented here due to paper length restrictions.

\section{Data analysis}

Analysis and coding of data explicitly took account of the vocabulary and anecdotes used by respondents to convey their emotional beliefs about the nature and purpose of higher education and academic work (Phillips \& Hardy, 2002). Code labels and related theoretical categories grounded in the words of respondents represented key techniques for ensuring participants' implicit meanings and beliefs were captured in the coding itself (Charmaz, 2006). All data was coded by the first author and discussed with the second author in order to sharpen theoretical sensitivity and identity connections (Saldaña, 2009).

\section{Findings}

\section{Importance of professional values}

Table 1 shows academics in lecturer and professor positions both expressed a strong response to statements indicative of the importance of professional values. A majority of professor (98 per cent) and lecturer (91 per cent) respondents indicated a preference for higher education to be promoted on the basis of 'educational need and academic standards principles'. Similarly, over 90 per cent of respondents in both groups professed a strong belief in universities being 'first and foremost learning institutions focused on intellectual rigour and scholarship' and that the 'primary purpose of academic work is to encourage scholarship and student learning'. In respect to student as consumer ideals (Furedi, 2011), a minority of professors (19 per cent) and lecturers ( 9 per cent) indicated a preference for academics offering students 'greater product choice as consumers'.

Lecturers and professors indicating a preference for professional values also provided openended comments to substantiate their professional identities. The following statements have been organised under category labels that reveal some separation from economic rationalist principles that 'distort the higher education process towards short-term profits' and which 'prevent the real university goals of education, research and community service from being achieved' (Professor/Science). 
Table 1: Professor and lecturer frequency responses to value statements.

\begin{tabular}{|l|r|r|}
\hline \multicolumn{1}{|c|}{ Value statements } & $\begin{array}{r}\text { Professor } \\
\text { frequencies }\end{array}$ & $\begin{array}{r}\text { Lecturer } \\
\text { frequencies }\end{array}$ \\
\hline 1. Higher education is best promoted on the basis of..? & 1 & 10 \\
A. Market-demand and user-pays principles (M) & 46 & 127 \\
B. Educational need and academic standards principles (P) & 0 & 2 \\
$\quad$ Missing data & & \\
\hline 2. Universities are first and foremost..? & 44 & 130 \\
A. Learning institutions focused on intellectual rigour and $\quad$ & 3 & 7 \\
$\quad$ scholarship (P) & 0 & 2 \\
B. Business institutions focused on income generation and cost & & \\
$\quad$ minimisation (M) & 43 & 132 \\
$\quad$ Missing data & & 6 \\
\hline 3. The primary purpose of academic work is to..? & 1 & 1 \\
A. Encourage scholarship and student learning (P) & 3 & 13 \\
B. Generate income via external research grants and industry & & 123 \\
$\quad$ linkages (M) & 9 & 3 \\
\hline Missing data & 38 & 139 \\
\hline 4. Academics need to offer students..? & 0 & \\
A. Greater product choice as consumers (M) & 47 & \\
B. Structured learning focused programs (P) & & \\
$\quad$ Missing data & & \\
\hline Totals & & \\
\hline
\end{tabular}

Notes: professor positions ( 1 dean, 6 heads of school, 17 professors, 19 associate professors, 4 program heads); lecturer positions (35 senior lecturers, 84 lecturers, 20 associate lecturers). $\mathrm{M}=$ managerial values, $\mathrm{P}=$ professional values.

\section{Education and universities are about more than economic factors}

Academics shared a deep-seated antipathy to education being 'viewed as an item for economic transactions' (Associate Professor/Science) that 'can be bought like Ipods or cars' (Professor/Science). In challenging the precepts of economic rationalism, respondents conceived education in broader social terms:

Education is about more than economic factors; it is the basis of a civilised society and is the means for people to improve themselves and for the transmission and generation of knowledge. (Lecturer/Science)

There are a number of Australian universities who have moved away from educational values to business, economic values. It is important that universities and governments remember what universities are for - the development and dissemination of education and knowledge. (Lecturer/Arts)

I don't believe that education should be viewed as an item for economic transactions. I believe that the primary objective of tertiary education is to serve humanity and the fostering of human qualities. (Associate Professor/Science) 


\section{Education should not be diluted by market forces or business interests}

Academics also made strident comments that market forces and business interests should not be allowed to 'determine what knowledge needs to be kept or transferred, or what is intellectually valued' in higher education (Senior Lecturer/Science). One respondent reinforced the view that market forces were 'devaluing the two-way process of learning' and "contributing to an attitude from students that they are "purchasing" a degree rather than "investing" in an opportunity to learn' (Lecturer/Law). Other respondents echoed a similar theme that education should not be commodified or sullied by business interests:

[Discipline] schools should be a place for the open exploration of ideas. Ideally, the focus of education should be teaching, not catering to 'monied interests'. (Professor/Education)

Commodification of education devalues the two-way process of learning. Higher education should foster higher-order thinking, innovation and an ability to critique. (Lecturer/Business)

\section{Students are not consumers or arbiters of what needs to be known}

Academic respondents ridiculed the managerial idea that students were customers or consumers of higher education (Furedi, 2011; Sharrock, 2000). An anti-consumer discourse was justified in terms of 'students do not always know what they need to know' (Lecturer/Arts), 'are poorly equipped to make judgements on what they need for their chosen interest or career' (Lecturer/Science), and prefer not to be 'marketed at!' (Professor /Science):

I don't care if I have four or two-hundred students. I'm a teacher, I'm not a manager. For me I don't want to look at, you know, there is that much money I get out of this student or of that student. That's not a consideration for me...I don't see students at all as customers. (Lecturer/Business)

Reflecting educational beliefs and goals that affirm the centrality of learning and student skill development (Nixon, 1997), one respondent strongly rejected the idea that the 'national need for high-level skills (and the research expertise this supports) can be satisfied by student preferences alone' (Professor/Science). Another professor (head of school) went further in showing his contempt for consumerism suggesting it is a 'disease destroying this planet' and if the university was to 'happily sell consumers degrees' then he would 'rather weed gardens than work here' (Professor/Arts).

\section{Discussion}

\section{Reflections on academic identity tensions}

Understanding academic identity in terms of contradictory values is an under-researched area of research in higher education, although there are some notable exceptions (Billot, 2010; Churchman, 2006; Churchman \& King, 2009; Winter, 2009). Our study has provided some insights into academic identity tensions in a public university environment by focusing on the economic (managerial) and broader academic (professional) values and purposes of higher education and academic work (McArthur, 2011; Winter, 2009).

Although the on-line survey response is somewhat limited in overall size and scope, the value statements do indicate some identity tensions among academics in respect to higher education 
being reduced in purpose to a narrow, economic-oriented function (Hussey \& Smith, 2010; McArthur, 2011). Identity tensions are particularly acute among academics in the science discipline, perhaps due to the fact commercialisation 'has taken hold most firmly' in this part of the institution (Bok, 2003, p. 5). In stressing their professional identities (Nixon 1996, 1997), respondents called into question the ethical basis of a higher education system which privileges short-term economic factors and neglects the long-term community service role of educating students, its contribution to a greater social justice, and generating knowledge for society more broadly (McArthur, 2011; Scott, 2004). Although these calls may be dismissed by critics as "just a rant against the inevitable difficulties of expanding the provision of higher education' (Hussey \& Smith, 2010, p. vii), they still should alert us to the important role traditional beliefs and values play in connecting academics to their roles, universities, and the broader society.

Comments made by discipline-based academics do suggest values play an important role in highlighting the cultural, intellectual and pedagogical consequences of conceiving higher education in narrow economic terms (Barnett, 2011; Hussey \& Smith, 2010). For a number of academics, the conception of higher education as a 'business' signifies the dilution of the professional role of educating students and a means of stifling critical thinking and the open exploration of ideas (Hussey \& Smith, 2010). Indeed, anti-business and anti-consumer sentiments expressed by academics in this study echo comments made by academics in earlier studies suggesting identity tensions are firmly entrenched in the academic heartland of Australian public universities (Churchman, 2006; Churchman \& King, 2009; Winter \& Sarros, 2002).

Pressured to engage with students as consumers, many academics despair that learning and scholarship, key values underpinning the academic profession (Bexley, James, \& Arkoudis, 2011), are being compromised with the increasing marketisation of higher education (Furedi, 2011). However, whether learning and scholarship is impaired as a direct result of a student as customer relationship is difficult to ascertain given the wide range of other factors (e.g., individual motivations of students and staff; employers decisions to give staff paid time to study, etc) affecting the outcome. As Barnett (2011) makes clear, 'there is no reason to believe that the presence of a market dimension [in] the pedagogical relationship will have a significance that overrides all those other factors' (p. 42). With this caveat in mind, we suggest that whilst higher education is increasingly defined in corporate terms (Bok, 2003; Hussey \& Smith, 2010), the actual ramifications such values and organisation has for pedagogy and the quality of learning may not be altogether clear. A possible fruitful area of future research is investigations of how seemingly contradictory managerial (economicprivate) and professional (liberal-social) values can coalesce in public universities and influence the quality of learning and scholarship.

\section{Conclusion}

Study findings reveal how academic identity tensions represent a distinct values-based response by academics to the changed reality of the public university prioritising the economic needs of the higher education market (Furedi, 2011; Hussey \& Smith, 2010). Positioning identity tension in such values-based terms reminds us that identities are 'continually in the process of being constructed, continually subject to change as the relations, practices and discourses which surround individuals change' (Halford \& Leonard, 1999, p. 109). 
In order for academics to 'take on' and 'live out' new identities that embody commercial ideas and practices, more attention should be given by university leaders to integrating the guiding principles and beliefs of academics across the disciplines. Furedi (2011) states bluntly this is perhaps too difficult a task in the current commercialised environment given it is likely sections of higher education leadership have internalised the ideology of marketisation to the point where they find it difficult to distinguish between an academic relationship and a commercial transaction' (p. 3). A discourse voiced by academics in this study could help connect and guide the managerial (economic) and professional (academic) arms of the university: educational principles should stand above market principles and business interests should not be allowed to determine primarily what knowledge needs to be kept, transferred or intellectually valued in higher education.

\section{References}

Albert, S., \& Whetten, D. (1985). Organizational identity. In L.L. Cummings \& B.M. Staw (Eds), Research in organizational behaviour, Vol. 7 (pp. 263-295). Greenwich, CT: JAI Press.

Ashforth, B.E. (2001). Role transitions in organisational life: An identity-based perspective. Mahwah, NJ: Lawrence Erlbaum Associates.

Barnett, R. (2011). The marketised university: Defending the indefensible. In M. Molesworth, R. Scullion, \& E. Nixon (Eds.), The marketisation of higher education and the student as consumer (pp. 39-51). London: Routledge.

Becher, T., \& Trowler, P. (2001). Academic tribes and territories: Intellectual inquiry and the cultures of disciplines. Milton Keyes, UK: Society for Research into Higher Education \& Open University Press.

Bexley, E., James, R., \& Arkoudis, S. (2011). The Australian academic profession in transition. Melbourne: Centre for the Study of Higher Education, The University of Melbourne.

Beyer, J.M. (1981). Ideologies, values, and decision making in organizations. In P.C. Nystrom \& W.H. Starbuck (Eds), Handbook of organizational design, Vol. 2 (pp.166202). New York: Oxford University Press.

Billot, J. (2010). The imagined and the real: Identifying the tensions for academic identity. Higher Education Research \& Development, 29(6), 709-721.

Bok, D. (2003). Universities in the marketplace: The commercialization of higher education. Princeton, NJ: Princeton University Press.

Brown, A.D., \& Humphreys, M. (2006). Organizational identity and place: A discursive exploration of hegemony and resistance. Journal of Management Studies, 43(2), 231-257.

Charmaz, K. (2006). Constructing grounded theory: A practical guide through qualitative analysis. London: Sage Publications.

Churchman, D. (2006). Institutional commitments, individual compromises: Identity-related responses to compromise in an Australian university. Journal of Higher Education Policy and Management, 28(1), 3-15.

Churchman, D., \& King, S. (2009). Academic practice in transition: Hidden stories of academic identities. Teaching in Higher Education, 14(5), 507-516.

Coady, T. (2000). Universities and the ideals of inquiry. In T. Coady (Ed.), Why universities matter: A conversation about values, means and directions (pp. 3-25). Sydney: Allen and Unwin.

Day, C., Kington, A., Stobart, G., \& Sammons, P. (2006). The personal and professional selves of teachers: Stable and unstable identities. British Educational Research Journal, 32(4), 601-616. 
Deem, R. (1998). 'New managerialism' and higher education: The management of performances and cultures in universities in the United Kingdom. International Studies in Sociology of Education, 8, 47-70.

Deem, R., Hillyard, S., \& Reed, M. (2008). Knowledge, higher education, and the new managerialism: The changing management of UK universities. Oxford: Oxford University Press.

Furedi, F. (2011). Introduction to the marketisation of higher education and the student as consumer. In M. Molesworth, R. Scullion, \& E. Nixon (Eds.), The marketisation of higher education and the student as consumer (pp. 1-7). London and New York: Routledge.

Halford, S., \& Leonard, P. (1999). New identities? Professionalism, managerialism and the construction of self. In M. Exworthy \& S.Halford (Eds.), Professionals and the new managerialism in the public sector (pp. 102-120). Buckingham, UK: Open University Press.

Henkel, M. (1997). Academic values and the university as corporate enterprise. Higher Education Quarterly, 51(2), 134-143.

Henkel, M. (2005). Academic identity and autonomy in a changing policy environment. Higher Education, 49, 155-176.

Hussey, T., \& Smith, P. (2010). The trouble with higher education: A critical examination of our universities. New York and London: Routledge.

Kenny, J.D. (2009). Managing a modern university: is it time for a rethink? Higher Education Research \& Development, 28(6), 629-642.

Kerlinger, F.N. (1986). Foundations of behavioral research. Third edition. New York: Holt, Rinehart and Winston.

Kolsaker, A. (2008). Academic professionalism in the managerialist era: a study of English universities. Studies in Higher Education, 33(5), 513-525.

Lewicki, R.J., Greenberger, D., \& Coyne, E. (2007). 'Dysfunctional' subcultures in organisations: Threat or a key to enhancing change? In Langan-Fox, J., Cooper, C.L., \& Klimoski, R.J. (Eds), Research companion to the dysfunctional workplace: Management challenges and symptoms (pp.441-459). Cheltenham, UK: Edward Elgar.

McArthur, J. (2011). Reconsidering the social and economic purposes of higher education. Higher Education Research \& Development, 30(6), 737-749.

Nixon, J. (1996). Professional identity and the restructuring of higher education. Studies in Higher Education, 21(1), 5-16.

Nixon, J. (1997). Regenerating professionalism within the academic workplace. In J. Broadbent, M. Dietrich, \& J. Roberts (Eds.), The end of the professions? The restructuring of professional work (pp. 86-103). London: Routledge.

Phillips, N., \& Hardy, C. (2002). Discourse analysis: Investigating processes of social construction. Thousand Oaks, CA: Sage Publications.

Saldaña, J. (2009). The coding manual for qualitative researchers. Los Angeles, CA: Sage Publications.

Scott, P. (2004). Ethics 'in' and 'for' higher education. Higher Education in Europe, 29(4), 439-450.

Sharrock, G. (2000). Why students are not (just) customers (and other reflections on life after George). Journal of Higher Education Policy and Management, 22(2), 149-164.

Sproull, L. (1981). Beliefs in organisations. In P.C. Nystrom, \& W.H. Starbuck (Eds.), Handbook of organisational design vol. 2 (pp. 203-223). Oxford, UK: Oxford University Press.

Sue, V.M, \& Ritter, L.A. (2007). Conducting online surveys. Los Angeles: Sage Publications. 
Teelken, C. (2012). Compliance or pragmatism: How do academics deal with managerialism in higher education? A comparative study in three countries. Studies in Higher Education, 37(3), 271-290.

Winter, R.P. (2009). Academic manager or managed academic? Academic identity schisms in higher education. Journal of Higher Education Policy and Management, 3(2), 121-131.

Winter, R.P., \& Sarros, J.C. (2002). Corporate reforms to Australian universities: Views from the academic heartland. Journal of Institutional Research, 11(2), 92-104. 